аспирант кафедры философии и социологии Адыгейского государственного университета

\section{ОЦЕНОЧНО-АФФЕКТИВНОЕ ВОСПРИЯТИЕ МОЛОДЕЖЬЮ РОССИЙСКОЙ ПОЛИЦИИ (ПО МАТЕРИАЛАМ СОЦИОЛОГИЧЕСКОГО ИССЛЕДОВАНИЯ)}

Аннотация:

В статье рассматриваются выявленные в ходе социологического исследования особенности оценочно-аффрективного восприятия образа полиции студенческой молодежью Юга России (Кубанский государственный университет, Южный федеральный университет и Адыгейский государственный университет). В анкете социологического опроса содержались вопросы, позволяющие определить основные характеристики деятельности полиции с точки зрения их соответствия социальным ожиданиям молодежи; восприятие студентами распространенных практик взаимодействия с сотрудниками правоохранительных органов. Установлена типологическая соотнесенность образа полиции в сознании молодежи, когда по оценочно-аффективному компоненту основная часть респондентов демонстрирует правокультурные установки целерационального типа. Это проявляется в оценке работы правоохранительных органов с точки зрения приоритета закона, защиты гражданских прав и свобод, независимости от других структур. В то же время фиксируется несоответствие между уровнем общеправовых и конкретно-юридических знаний, когда степень когнитивных представлений молодежи о нормативных границах взаимодействия полиции и рядовых граждан является невысокой.

\section{Ключевые слова:}

российская полиция, образ полиции, молодежь, молодежное сознание, правовая культура, оценочноаффективный компонент, правокультурные установки.
PhD student, Philosophy and Sociology Department, Adygea State University

EVALUATIVE AND AFFECTIVE PERCEPTION OF THE RUSSIAN POLICE BY THE YOUTH (BASED ON SOCIOLOGICAL RESEARCH)

\begin{abstract}
Summary:
The study reviews the evaluative and affective perception of the police image by the students in the southern regions of Russia (Kuban State University, Southern Federal University, and Adygea State University). The results of the sociological survey allow one to determine the basic characteristics of police activities from the standpoint of their compliance with the social expectations of the youth and the students' perception of the fact of interaction with police servants. Evaluative and affective component of the police image in the youth consciousness demonstrates the respondents' legal cultural attitudes of purposeful nature. The young people can assess the activities of the law enforcement agencies in terms of the priority of law, the protection of civil rights and freedoms, and the independence from other structures. At the same time, the discrepancy between the general and specific legal knowledge shows the insufficient level of students' cognitive representations on the standards of interaction between police servants and citizens.
\end{abstract}

Keywords:

Russian police, police image, youth, youth consciousness, legal culture, evaluative and affective component, legal cultural attitudes.

Современная российская молодежь неоднозначно воспринимает государственно-правовые институты, в частности систему правоохранительных органов. Анализ последних социологических исследований позволяет констатировать дифференцированность молодых россиян в восприятии полиции. И в этом проявляется состояние правосознания молодежи.

В исследованиях отечественных авторов, посвященных анализу правовой культуры и правосознания молодежи, отмечается, что у российских граждан на массовом уровне существует выраженный недостаток правовых знаний [1]. Западные ученые также подчеркивают невысокий уровень знаний граждан о функциях, нормативных принципах, целях и задачах работы подразделений полиции [2].

Судя по общероссийским и региональным исследованиям, уровень доверия к сотрудникам полиции за последние три года достиг максимального показателя в $46 \%$. В частности, исследование Всероссийского центра изучения общественного мнения (ВЦИОМ), проведенное в ноябре 2016 г., показывает, что доверие к сотрудникам полиции своего региона в 2016 г. выражают $47 \%$ россиян (в 2015 г. - 46 \%). Чаще, чем в среднем по выборке, об этом говорят 18-24-летние (55 \%). Однако другая часть граждан (47 \%) еще относится к полицейским с недоверием [3].

С целью выявления типологических особенностей образа российской полиции в сознании территориальных подгрупп студенческой молодежи нами был проведен социологический опрос 
в трех субъектах Южного федерального округа - Краснодарском крае (КК), Ростовской области (PO), Республике Адыгея (РА). Методом стандартизированного интервью было опрошено 297 студентов Кубанского государственного университета, 321 - Южного федерального университета и 345 - Адыгейского государственного университета. Достижение поставленной цели предполагает решение следующих задач: анализ типологических особенностей нормативно-правового компонента образа полиции в сознании молодежи; выявление содержания и динамики оценочно-афффективного восприятия студентами российской полиции по территориальным группам; характеристика фракторов формирования образа полиции в среде студенческой молодежи. Методом сбора эмпирического материала стал анкетный опрос.

Наряду с материалами собственных социологических исследований автором были привлечены в качестве источника информации результаты опроса студентов г. Ростова-на-Дону, реализованного Центром прикладных социологических исследований РГПУ в 2004 г. Методика опроса разработана А.В. Сахно и Г.С. Денисовой [4].

Оценочно-аффективный компонент образа полиции представлен в исследовании показателями восприятия молодежью качественных характеристик и степени эффрективности работы современной полиции. В анкете социологического опроса содержались вопросы, позволяющие определить: основные характеристики деятельности полиции с точки зрения их соответствия социальным ожиданиям молодежи; восприятие студентами распространенных практик взаимодействия с сотрудниками правоохранительных органов.

Ряд позиций оценочного блока образа полиции в сознании студентов сопоставлялся с результатами общероссийских опросов ВЦИОМ [5]. По совпадающим вопросам также отслеживалась динамика установок ростовской студенческой молодежи в 2004 и 2017 гг.

С точки зрения нормативных представлений студентов органы правопорядка должны защищать права и свободы граждан (от 73,8 до 86,6 \% опрошенных различных территориальных сегментов). И, как отмечают специалисты, «прогрессивное развитие государственности обеспечивается только тогда, когда правоохранительные органы защищают права, интересы и свободы человека» [6, с. 16]. Но, по данным опроса, молодежь Юга России практически в три раза реже отмечает реальное обеспечение полицией гражданских прав и свобод населения. По большей части студенты указывают на то, что полиция защищает интересы государства (от 42,9 до 52,7 \% респондентов), а также отстаивает собственные интересы (от 31 до 57,1 \% опрошенных) (рис. 1).

Территориальные особенности ответов студентов проявляются в том, что в Краснодарском крае меньшинство опрошенной молодежи фиксирует соответствие законодательно установленных и реально осуществляемых функций полиции. Немного выше данные показатели в студенческой среде Республики Адыгея (рис. 1).

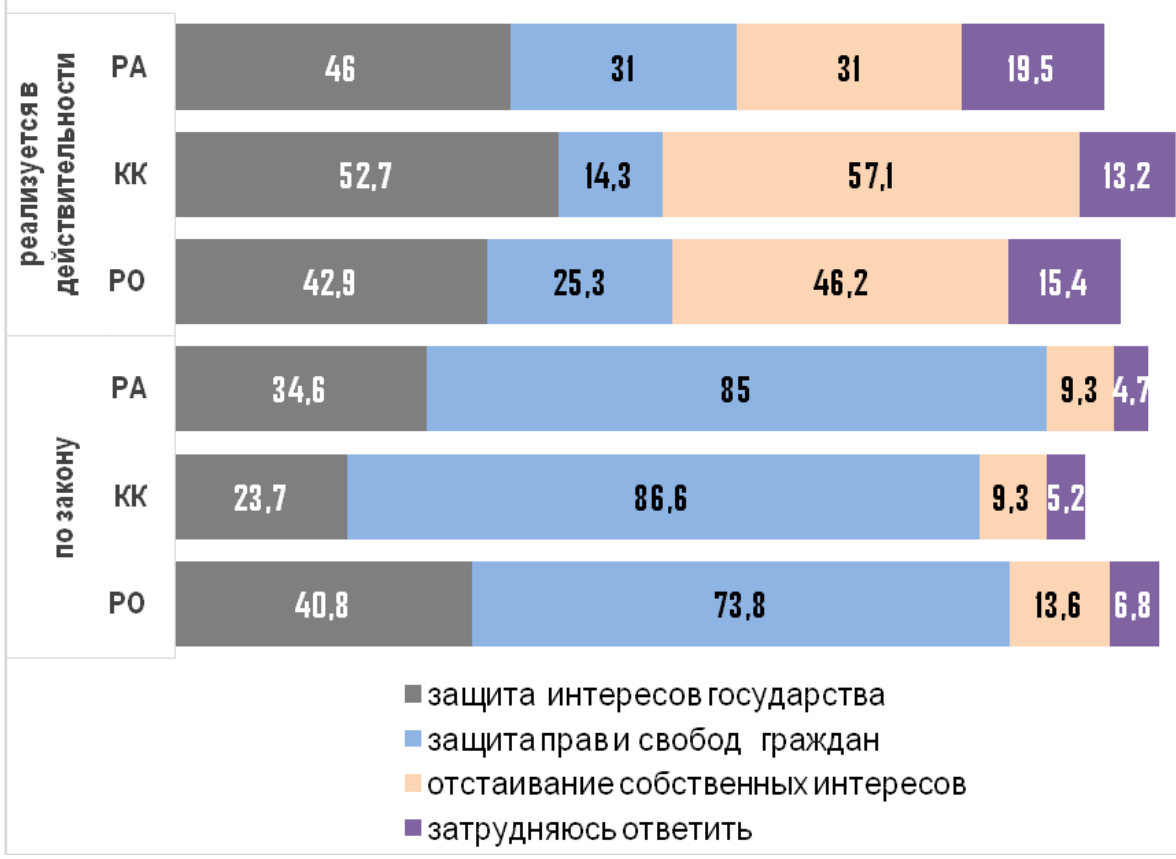

Рисунок 1 - Распределение ответов молодежи на вопросы: «Как Вы полагаете, в чем заключается главная функция полиции? Что, по Вашему мнению, в основном реализуется российской полицией в действительности?» (\%). Опрос 2017 г. 
Динамика оценочного компонента образа полиции в сознании молодежи ростовского региона показывает, что студенты отмечают рост государственно-охранительных ориентаций в деятельности органов правопорядка. Отмечали нацеленность действительной работы полиции на защиту интересов государства 14,8 \% респондентов в исследовании 2004 г. и 42,9 \% - в опросе 2017 г. Преследование собственных интересов в работе сотрудников органов правопорядка указывают несколько меньшее число современной молодежи (57,4 \% в 2004 г. и 46,2 \% в 2017 г.). Немного повышается также процент указаний на защиту полицией прав и свобод граждан: с 16,7 до $25,3 \%$ (рис. 2).

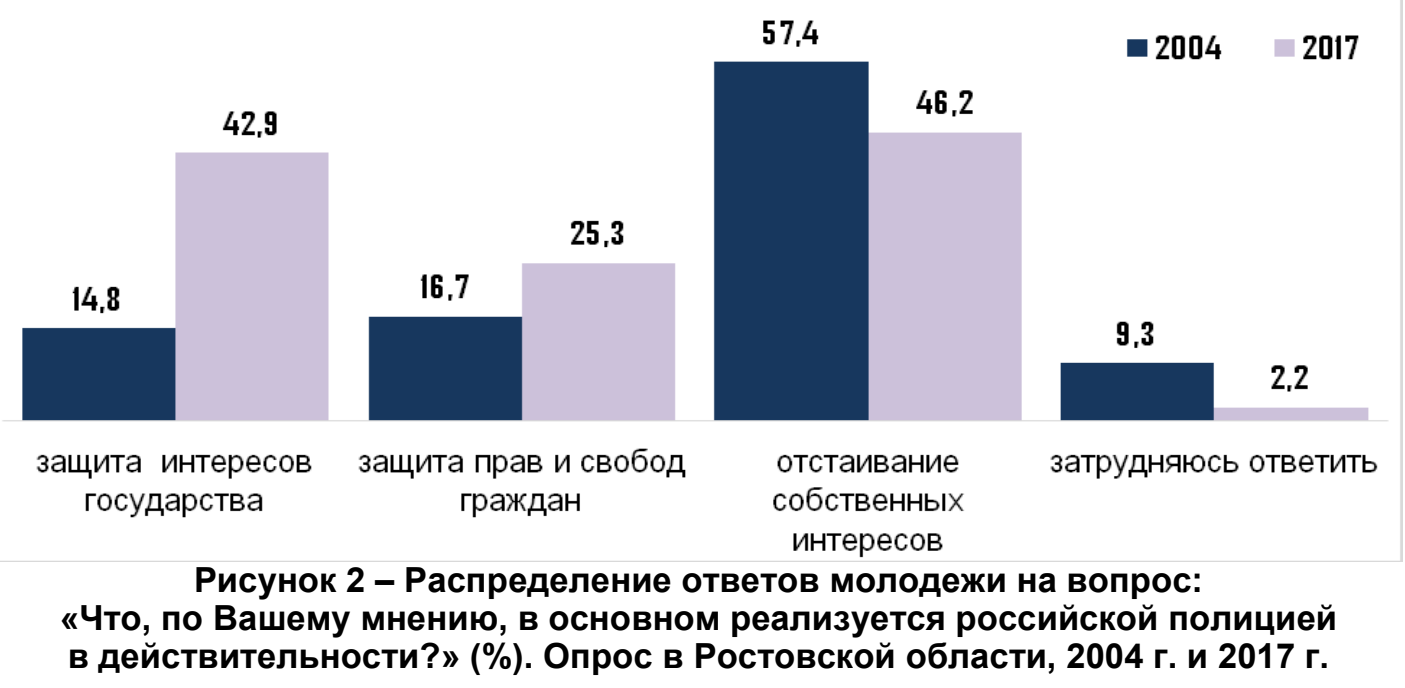

Выявленные относительно невысокие показатели уровня доверия молодежи к полиции и скорее средние оценки уровня эфффективности работы правоохранительных органов связаны с восприятием студентами степени независимости полиции от различных структур. Как показали результаты исследования 2017 г., с точки зрения молодежи, наиболее зависимы органы правопорядка от прокураторы (вариант ответа «полностью зависима» от 32,4 до 47,8 \% опрошенных в рассматриваемых территориальных группах) и законодательных структур (от 36,8 до 42,7 \% респондентов). Наиболее критичны в оценке уровня свободы полиции студенты из Краснодарского края (табл. 1).

Считают, что работа правоохранительных структур «в чем-то зависима, а в чем-то нет» от административных органов власти от 58,5 до 69,5 \% опрошенных в трех группах. Обращает на себя внимание, что значимая степень влияния на деятельность полиции со стороны криминальных структур отмечается 64,4 \% студентами в Ростовской области, 56,8 \% - в Краснодарском крае и 43 \% в Адыгее. Более всего свободна полиция, по мнению опрошенной молодежи, от влияния коммерческих организаций (от 40,6 до 62 \% респондентов выбрали вариант «полностью независима») и политических партий (от 38,8 до 46,6 \%). В целом чаще выражает отрицательные оценки, касающиеся независимости работы правоохранительных органов, молодежь краснодарских и ростовских вузов (табл. 1).

Таблица 1 - Распределение ответов молодежи на вопрос:

«Как вы полагаете, насколько в своей работе полиция независима

от следующих органов и организаций» (в \%). Опрос 2017 г.

\begin{tabular}{|c|c|c|c|c|}
\hline № & Варианты ответов & PO & КК & PA \\
\hline 1 & 2 & 3 & 4 & 5 \\
\hline & \multicolumn{4}{|c|}{ Административные органы власти } \\
\hline 1 & полностью независима & 19,8 & 7,4 & 23,5 \\
\hline 2 & в чем-то зависима, а в чем-то автономна & 58,5 & 69,5 & 62,7 \\
\hline \multirow[t]{2}{*}{3} & полностью зависима & 21,7 & 23,2 & 13,7 \\
\hline & \multicolumn{4}{|c|}{ Законодательные органы власти } \\
\hline 1 & полностью независима & 20,8 & 16,7 & 21,8 \\
\hline 2 & в чем-то зависима, а в чем-то автономна & 42,5 & 40,6 & 36,6 \\
\hline \multirow[t]{2}{*}{3} & полностью зависима & 36,8 & 42,7 & 41,6 \\
\hline & \multicolumn{4}{|c|}{ Прокуратура } \\
\hline 1 & полностью независима & 18,1 & 15,2 & 14,1 \\
\hline 2 & в чем-то зависима, а в чем-то автономна & 49,5 & 37,0 & 42,4 \\
\hline \multirow[t]{2}{*}{3} & полностью зависима & 32,4 & 47,8 & 43,4 \\
\hline & \multicolumn{4}{|c|}{ Коммерческие организации (бизнес) } \\
\hline 1 & полностью независима & 42,5 & 40,6 & 62,0 \\
\hline
\end{tabular}


Продолжение таблицы 1

\begin{tabular}{|c|c|c|c|c|}
\hline 1 & 2 & 3 & 4 & 5 \\
\hline 2 & в чем-то зависима, а в чем-то автономна & 47,2 & 54,2 & 23,0 \\
\hline 3 & полностью зависима & 10,4 & 5,2 & 15,0 \\
\hline & \multicolumn{4}{|c|}{ Криминальные структуры } \\
\hline 1 & полностью независима & 26,9 & 29,5 & 34,0 \\
\hline 2 & в чем-то зависима, а в чем-то автономна & 64,4 & 56,8 & 43,0 \\
\hline 3 & полностью зависима & 8,7 & 13,7 & 23,0 \\
\hline & \multicolumn{4}{|c|}{ Политические партии } \\
\hline 1 & полностью независима & 38,8 & 34,7 & 46,6 \\
\hline 2 & в чем-то зависима, а в чем-то автономна & 47,6 & 48,4 & 38,8 \\
\hline 3 & полностью зависима & 13,6 & 16,8 & 14,6 \\
\hline
\end{tabular}

Студенты отмечают широкое использование сотрудниками полиции своего служебного положения в личных целях (от 56 до 63,6 \% респондентов трех территориальных субъектов), распространенность поборов и взяточничества (от 48,1 до 63,6 \% опрошенных). Во вторую очередь молодежь фиксирует широкие масштабы бюрократизма и волокиты в правоохранительных органах (от 25 до 44,9 \% студентов трех групп), грубое обращение с задержанными (от 29,1 до 41,1%) (табл. 2, 3).

Таблица 2 - Распределение ответов молодежи на вопрос:

«Как Вы считаете, В какой степени в деятельности современной полиции распространены следующие явления?» (\%)

\begin{tabular}{|c|c|c|c|c|c|}
\hline \multirow{2}{*}{ № } & \multirow{2}{*}{ Варианты ответов } & 2004 & \multicolumn{3}{|c|}{2017} \\
\hline & & PO & PO & KK & PA \\
\hline & \multicolumn{5}{|c|}{ Использование служебного положения в личных целях } \\
\hline 1 & широко распространены & 66,0 & 63,6 & 64,9 & 56,0 \\
\hline 2 & отчасти распространены & 30,2 & 32,7 & 30,9 & 41,3 \\
\hline \multirow[t]{2}{*}{3} & практически не встречаются & 3,8 & 3,7 & 4,1 & 2,8 \\
\hline & \multicolumn{5}{|c|}{ Поборы и взяточничество } \\
\hline 1 & широко распространены & 53,9 & 63,6 & 54,2 & 48,1 \\
\hline 2 & отчасти распространены & 38,5 & 32,7 & 42,7 & 49,1 \\
\hline \multirow[t]{2}{*}{3} & практически не встречаются & 7,6 & 3,7 & 3,1 & 2,8 \\
\hline & \multicolumn{5}{|c|}{ Равнодушие и низкая культура обращения с гражданами } \\
\hline 1 & широко распространены & 34,7 & 36,4 & 28,1 & 17,6 \\
\hline 2 & отчасти распространены & 55,8 & 51,4 & 59,4 & 60,2 \\
\hline \multirow[t]{2}{*}{3} & практически не встречаются & 9,5 & 12,1 & 12,5 & 22,2 \\
\hline & \multicolumn{5}{|c|}{ Бюрократизм, формализм, волокита } \\
\hline 1 & широко распространены & 44,2 & 44,9 & 35,8 & 25,0 \\
\hline 2 & отчасти распространены & 34,6 & 44,9 & 56,8 & 51,0 \\
\hline 3 & практически не встречаются & 21,2 & 10,3 & 7,4 & 24,0 \\
\hline
\end{tabular}

Больше половины опрошенной молодежи указывает на частичную распространенность в полицейской среде равнодушия и низкой культуры обращения с гражданами, искажения фактов и фральсификации материалов. Менее всего, с точки зрения студентов, встречаются в работе правоохранительных структур фракты непринятия заявлений о преступлениях (вариант «практически не встречается» выбрали от 18,9 \% до 40 \% опрошенных). Территориальная специфика ответов респондентов обнаруживает больший удельный вес критичных оценок в группах ростовской и краснодарской молодежи (табл. 2, 3).

Таблица 3 - Распределение ответов молодежи на вопрос:

«Как Вы считаете, в какой степени в деятельности современной полиции распространены следующие явления?» (\%)

\begin{tabular}{|c|c|c|c|c|c|}
\hline \multirow{2}{*}{ № } & \multirow{2}{*}{ Варианты ответов } & 2004 & \multicolumn{3}{|c|}{2017} \\
\hline & & PO & PO & KK & PA \\
\hline \multirow[t]{2}{*}{1} & 2 & 3 & 4 & 5 & 6 \\
\hline & \multicolumn{5}{|c|}{ Непринятие заявлений о преступлениях } \\
\hline 1 & широко распространены & 29,4 & 24,5 & 18,8 & 15,0 \\
\hline 2 & отчасти распространены & 39,2 & 56,6 & 49,0 & 45,0 \\
\hline \multirow[t]{2}{*}{3} & практически не встречаются & 31,4 & 18,9 & 32,3 & 40,0 \\
\hline & \multicolumn{5}{|c|}{ Грубость во взаимоотношениях полиции и граждан по поводу жалоб и заявлений } \\
\hline 1 & широко распространены & 30,8 & 34,6 & 24,0 & 18,8 \\
\hline 2 & отчасти распространены & 48,1 & 46,7 & 54,2 & 55,4 \\
\hline 3 & практически не встречаются & 21,1 & 18,7 & 21,9 & 25,7 \\
\hline
\end{tabular}


Продолжение таблицы 3

\begin{tabular}{|c|c|c|c|c|c|}
\hline 1 & 2 & 3 & 4 & 5 & 6 \\
\hline & \multicolumn{5}{|c|}{ Искажение фактов, фальсификация материалов } \\
\hline 1 & широко распространены & 25,0 & 29,0 & 21,9 & 23,1 \\
\hline 2 & отчасти распространены & 55,8 & 52,3 & 52,1 & 42,3 \\
\hline 3 & практически не встречаются & 19,2 & 18,7 & 26,0 & 34,6 \\
\hline & \multicolumn{5}{|c|}{ Грубое обращение с задержанными } \\
\hline 1 & широко распространены & 54,7 & 41,1 & 35,4 & 29,1 \\
\hline 2 & отчасти распространены & 35,9 & $\mathbf{4 7 , 7}$ & 56,3 & 55,3 \\
\hline 3 & практически не встречаются & 9,4 & 11,2 & 8,3 & 15,5 \\
\hline
\end{tabular}

По данному блоку вопросов результаты опроса ростовской молодежи в 2017 г. можно сопоставить с исследованием 2004 г. Сравнительный анализ показывает, что процентные показатели оценок студентов по многим позициям практически не изменились. Можно отметить, что на современном этапе среди молодежи вырос процент указаний на широкую распространенность в полиции взяточничества (53,9 \% в 2004 г. против 63,6 \% в 2017 г.), но уменьшились, с их точки зрения, показатели грубого обращения с задержанными (54,7 \% против 41,1 \% соответственно) (табл. 2, 3).

В 2011 г. произошло реформирование работы Министерства внутренних дел России. 24 декабря 2009 г. президентом РФ был подписан Указ о совершенствовании деятельности МВД, предполагающий реформирование системы органов внутренних дел. В качестве важнейших направлений реформы выступали организационные и кадровые преобразования, а также материальное обеспечение сотрудников ОВД [7, с. 39]. В соответствии с федеральным законом «О полиции» милиция официально прекратила свое существование в стране.

Как отмечает В. Черников, «к концу первого десятилетия XXI в. становилось все очевиднее, что государственный институт, именуемый “милиция", исчерпал себя как по форме, так и по содержанию. Если не сказать больше - реальностью становилась дискредитация милицией своего предназначения как органа охраны правопорядка» [8]. Полномасштабная реформа была также связана с переаттестацией сотрудников МВД, что в итоге привело к сокращению более 20 \% от штатной численности работников правоохранительных органов.

В этом контексте студентам задавался вопрос о том, как переименование российской милиции в полицию отразилось на ее работе. Материалы проведенного опроса показывают, что подавляющее большинство опрошенной молодежи не усматривает принципиальных изменений в работе правоохранительных органов после их переименования. Отметили вариант «ничего не изменилось» от 78,1 до 85,6 \% опрошенных различных территориальных групп (рис. 3).

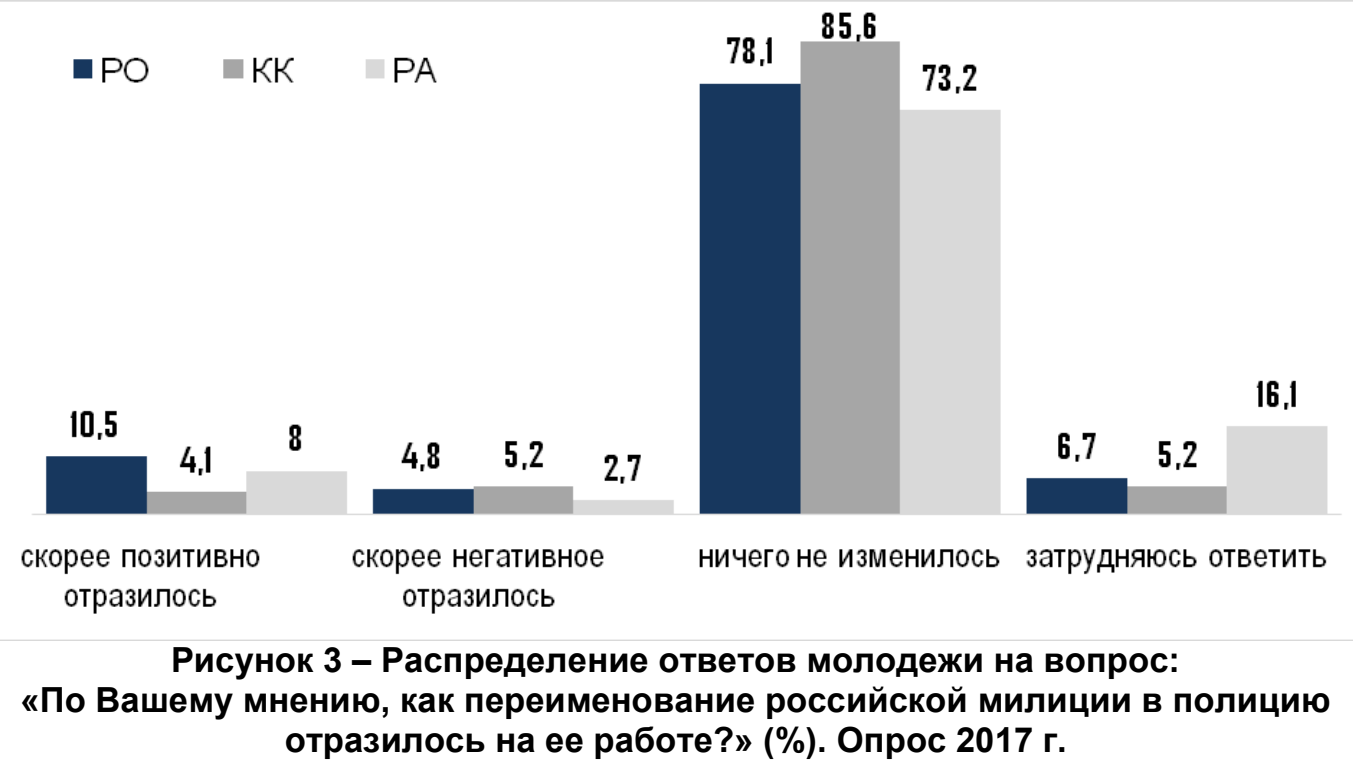

Оценочно-аффективное измерение образа полиции предполагает изучение фракторов, которые, с точки зрения молодежи, могут оказать воздействие на укрепление общественного порядка и усиление борьбы с преступностью.

Результаты опроса в 2017 г. показали, что, с точки зрения подавляющего большинства опрошенной молодежи, на эффективность работы полиции окажут серьезное влияние мероприятия по повышению качества отбора и профрподготовки сотрудников органов правопорядка (от 80,2 до 90,2 \% опрошенных трех различных территориальных сегментов). Усиление контроля за 
служебной деятельностью полиции также улучшит работу правоохранительных структур, по мнению более 80 \% опрошенных студентов.

Позитивное влияние на эффективность работы полиции может оказать и широкое привлечение общественности к борьбе с преступностью и охране общественного порядка (от 56,3 до $72,1 \%$ респондентов трех групп). Улучшение материально-технической оснащенности полиции также является фактором, положительно влияющим на качество деятельности правоохранительных органов, с точки зрения более половины опрошенных (от 59,8 до 63,3 \%). В то же время существенное увеличение денежного содержания сотрудников полиции особо не изменит эффрективности их работы, по мнению примерно половины студентов (от 45,1 до 53,7 \%).

Однако предоставление больших прав и полномочий сотрудникам полиции, наоборот, ухудшит ситуацию с соблюдением правопорядка, с точки зрения половины студентов Ростовской области $(54,9 \%)$ и Краснодарского края (56,3 \%). Молодежь Адыгеи чаще всего отмечает, что подобная мера особо не повлияет на эффективность работы полиции $(50,9 \%)$. В целом ростовские и краснодарские студенты и в данном вопросе более критичны в оценке возможных мер по повышению результативности работы органов правопорядка, чем республиканская молодежь.

Сравнивая материалы опроса ростовских студентов в 2004 и 2017 гг., можно увидеть, что до реализации реформы полиции подавляющее большинство молодежи считало, что эффективность работы правоохранительных органов повысится в случае улучшения материально-технической оснащенности полиции (92,5 \%), увеличения денежного содержания сотрудников полиции $(81,5 \%)$. Тринадцать лет спустя студенты уже гораздо ниже оценивают результативность подобных нововведений (в первом случае в 1,5 раза ниже, во втором - в 2,7 раза). Более оптимистичны студенты в 2004 г. в отношении предоставления больших прав и полномочий сотрудникам полиции. Считали, что данный фрактор укрепит общественный порядок, в 45,3 \% случаев в 2004 г. и только $14,7 \%$ - в 2017 г.

В ходе исследования образа полиции в сознании молодежи респондентам задавались вопросы, измеряющие оценку ими работы региональных органов правопорядка. Ответы сопоставлялись с результатами общероссийских исследований отношения населения к работе полиции. В частности, по результатам многолетних опросов ВЦИОМ уровень доверия к полиции с 2005 до 2012 г. не превышал 35 \%. С 2013 по 2016 г. показатели доверия немного повысились и составляли $46-47 \%$ (табл. 4).

Таблица 4 - Доверяете ли Вы сотрудникам полиции вашего региона? (\%). Опрос населения РФ [9]

\begin{tabular}{|l|c|c|c|c|c|c|c|}
\hline \multicolumn{1}{|c|}{ Ответ } & $\mathbf{2 0 0 5}$ & $\mathbf{2 0 0 9}$ & $\mathbf{2 0 1 0}$ & $\mathbf{2 0 1 2}$ & $\mathbf{2 0 1 3}$ & $\mathbf{2 0 1 5}$ & $\mathbf{2 0 1 6}$ \\
\hline Определенно доверяю & 8 & 6 & 3 & 3 & 7 & 14 & 14 \\
\hline Скорее доверяю & 29 & 32 & 29 & 32 & 39 & 32 & 33 \\
\hline Скорее не доверяю & 39 & 35 & 37 & 40 & 34 & 23 & 24 \\
\hline Определенно не доверяю & 18 & 18 & 21 & 21 & 11 & 23 & 23 \\
\hline Затрудняюсь ответить & 5 & 10 & 11 & 5 & 9 & 8 & 6 \\
\hline
\end{tabular}

Результаты регионального исследования в 2017 г. показали, что молодежь демонстрирует показатели доверия к полиции, в среднем соответствующие общероссийским данным. Между тем по территориям выявляются различия, когда наименьший уровень доверия сотрудникам правоохранительных органов демонстрируют студенты Ростовской области с показателем 41,8 \%; далее следуют респонденты Краснодарского края - 45,9 \%; и немного большая степень доверия наблюдается среди молодежи Адыгеи - 53,6 \% (рис. 4).

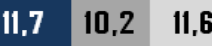

$$
\square \mathrm{PO}-\mathrm{KK} \quad \mathrm{PA}
$$

определенно не доверяю

скорее не доверяю

скорее доверяю

\section{1,1} 22,4

15,2

\section{1,1}

43,9

42,9

определенно доверяю

$\begin{array}{llll}10,7 \quad 2 & 10,7\end{array}$

15,5

21,4

19,6

затрудняюсь ответить

Рисунок 4 - Распределение ответов молодежи на вопросы: «Доверяете ли Вы сотрудникам полиции Вашего региона?» (\%). Опрос 2017 г. 
По данным общероссийских опросов ВЦИОМ, большинство населения России оценивает работу правоохранительных органов на среднем уровне (49 \% - в 2005 г., 52 \% - в 2013 г. и 47 \% - в 2016 г.). Немного растет число россиян, которые характеризуют работу полиции как хорошую. В 2015-2016 гг. каждый четвертый респондент оценил деятельность данного правоохранительного института выше среднего, тогда как каждый пятый - ниже среднего (табл. 5).

Таблица 5 - Как Вы в целом оцениваете работу полиции в Вашем регионе? (\%). Опрос населения РФ [10]

\begin{tabular}{|l|c|c|c|c|c|}
\hline \multicolumn{1}{|c|}{ Оценка } & $\mathbf{2 0 0 5}$ & $\mathbf{2 0 0 9}$ & $\mathbf{2 0 1 3}$ & $\mathbf{2 0 1 5}$ & $\mathbf{2 0 1 6}$ \\
\hline Очень хорошо & 2 & 1 & 3 & 2 & 2 \\
\hline Хорошо & 11 & 13 & 18 & 23 & 22 \\
\hline Средне & 49 & 50 & 52 & 46 & 47 \\
\hline Плохо & 27 & 21 & 18 & 15 & 15 \\
\hline Очень плохо & 6 & 6 & 3 & 5 & 6 \\
\hline Затрудняюсь ответить & 5 & 9 & 6 & 9 & 8 \\
\hline
\end{tabular}

Результаты опроса молодежи Юга России в 2017 г. показывают, что молодежь в двух территориальных подгруппах оценивает эффрективность работы полиции лучше, чем население России в целом. Выше среднего оценивает деятельность органов правопорядка каждый пятый респондент в ростовском сегменте и уже каждый третий студент в краснодарской и адыгейской группах. Средние оценки выставляют работе полиции от 44,2 до 49,1 \% молодежи Юга России. Выбирают варианты ответов «плохо» и «очень плохо» 17,5 \% студентов Ростовской области, 12,2 \% - в Краснодарском крае, 8,1 \% - в Республике Адыгея (рис. 5).

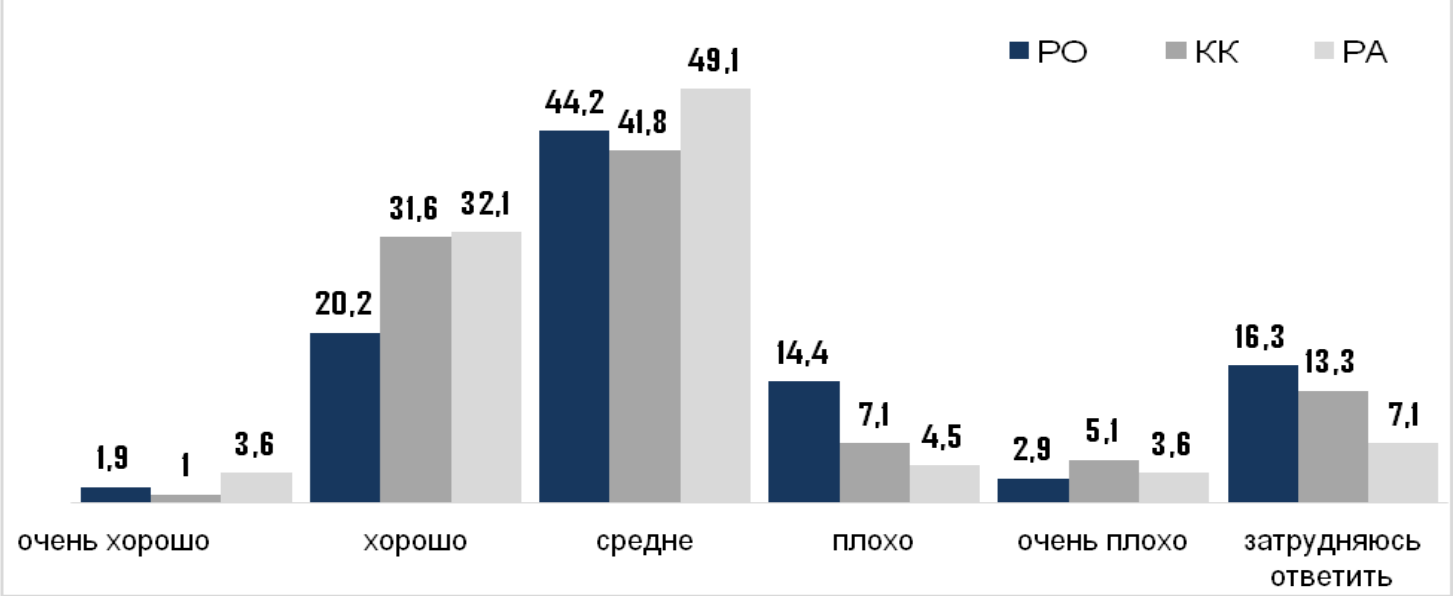

Рисунок 5 - Распределение ответов молодежи на вопросы: «Как Вы в целом оцениваете работу полиции в Вашем регионе?» (\%). Опрос 2017 г.

Выявленные оценки работы современной полиции влияют на поведенческие установки молодежи. В случае возникновения угрозы жизни, здоровью или благополучию далеко не все студенты обратятся в правоохранительные органы, хотя все же большая часть опрошенных пойдет в полицию - 55,7 \% в Ростовской области, 65,3 \% - в Краснодарском крае и 59,3 \% - в Адыгее. Второй по степени популярности ответ - «обращусь к близким, родственникам» (52,8 \% опрошенных в первой группе, 35,7 \% - во второй и 31,9 \% - в третьей). Третья часть ростовских студентов, пятая краснодарской молодежи и шестая адыгейских респондентов попросят помощи у друзей и знакомых. Если смотреть по совокупности ответов, то к родным, близким и друзьям обратятся более 80 \% студентов из Ростова-на-Дону, около 60 \% молодежи Краснодара и чуть меньше половины опрошенных Адыгеи. В другие правоохранительные органы (суд, прокуратура) обратится за помощью шестая часть ростовчан, пятая краснодарцев и четверть студентов из Майкопа. Ориентированы на помощь гражданских правозащитных организаций, а также на самостоятельное обеспечение своей безопасности в большей степени студенты ростовского и краснодарского сегментов, чем адыгейской группы (табл. 6).

Внутри ростовского сегмента за прошедшие 13 лет выросло число студентов, которые планируют в случае необходимости обращаться в полицию (с 38,9% в 2004 г. до 55,7 \% в 2017 г.), также растет ориентация на помощь родных и близких (33,3 против 52,8 \%) и самостоятельное обеспечение своей безопасности (3,7 против 17 \%). Фиксируется повышение доверия к гражданским правозащитным организациям (в 2004 г. никто не планировал обращаться туда, а в 2017 г. этот вариант выбрало 17 \% опрошенных) (табл. 6). 
Таблица 6 - Распределение ответов молодежи на вопрос: «Куда Вы обратитесь за помощью в случае возникновения угрозы Вашей жизни, здоровью или благополучию?» (\%)

\begin{tabular}{|c|c|c|c|c|c|}
\hline \multirow{2}{*}{ № } & \multirow{2}{*}{ Я обращусь: } & \multirow{2}{*}{$\begin{array}{c}2004 \\
\text { PO }\end{array}$} & \multicolumn{3}{|c|}{2017} \\
\hline & & & PO & KK & PA \\
\hline 1 & в полицию & 38,9 & 55,7 & 65,3 & 59,3 \\
\hline 2 & в иные правоохранительные органы (суд, прокуратура) & 18,5 & 15,1 & 22,4 & 26,5 \\
\hline 3 & к близким, родственникам & 33,3 & 52,8 & 35,7 & 31,9 \\
\hline 4 & к друзьям и знакомым & 27,8 & 34,0 & 22,4 & 15,0 \\
\hline 5 & в частные охранные и детективные агентства & 5,6 & 9,4 & 5,1 & 3,5 \\
\hline 6 & в гражданские правозащитные организации & - & 12,3 & 12,2 & 1,8 \\
\hline 7 & в криминальные структуры & - & 6,6 & 4,1 & 4,4 \\
\hline 8 & самостоятельно обеспечу свою безопасность & 3,7 & 17,0 & 19,4 & 9,7 \\
\hline 9 & ничего предпринимать не буду & - & - & 1,0 & 0,9 \\
\hline 10 & зависит от ситуации & 4,2 & 0,9 & 1,0 & 0,9 \\
\hline 11 & затрудняюсь ответить & 2,7 & 4,7 & 6,1 & 8,0 \\
\hline & Итого & 134,7 & 208,5 & 194,7 & 161,9 \\
\hline
\end{tabular}

Анализ оценочно-эффективного восприятия полиции позволяет заключить, что эффеективность работы правоохранительных органов молодежью Юга России характеризуется скорее как удовлетворительная. Это проявляется в низких оценках уровня реализации сотрудниками полиции своих нормативных полномочий и обязанностей по обеспечению прав и свобод граждан; сказывается мнение молодых людей о зависимости полиции от других властных органов и росте государственно-охранительных ориентаций в ее работе, распространении взяточничества, использовании служебного положения в личных целях и пр. Вместе с тем студенты Юга России немного выше оценивают эффективность работы полиции в регионе их проживания, чем население РФ в целом, а показатели доверия к органам правопорядка соответствуют общероссийским (по данным ВЦИОМ).

Реализованная в 2011 г. реформа ОВД, переименование милиции в полицию не принесли, с точки зрения опрошенных студентов, принципиальных позитивных подвижек в работе органов правопорядка. Кроме того, большая часть молодежи не прогнозирует положительного эффекта от еще большего увеличения материального обеспечения, технической оснащенности сотрудников полиции, а также предоставления им более широких полномочий. Зато повышение качества отбора и профессиональной подготовки работников правоохранительных органов, усиление контроля за их работой должно, с точки зрения молодежи, принести ощутимый эффект.

Таким образом, на уровне аффрективно-оценочного компонента образа полиции в сознании молодежи фиксируются выраженные целерациональные доминанты. Наиболее концентрированно они представлены в краснодарском и ростовском сегментах молодежи и менее выражены в адыгейской группе.

Динамика образа полиции/милиции в сознании ростовской молодежи также связана с ростом целерационального типа правовых ориентаций. Более заметна и субъектная направленность установок ростовских студентов, которые в большинстве случаев намерены обеспечивать свою правовую защищенность через родных, друзей или самостоятельно.

\section{Ссылки:}

1. Зубок Ю.А., Чупров В.И. Правовая культура молодежи в ракурсе трансформационных стратегий // Социологические исследования. 2006. № 6. С. 14-17.

1. Hinds L. Youth, police legitimacy and informal contact // Journal of Police and Criminal Psychology. 2009. Vol. 24 , no. 1. P. 10-21; Murphy K., Hinds L, Fleming J. Encouraging public cooperation and support for police // Policing and Society. 2008. Vol. 18, no. 2. P. $136-155$

2. Полиция: доверие и оценки [Электронный ресурс] : пресс-выпуск ВцИОМ № 3239. URL: https://wciom.ru/index.php?id=236\&uid=115938 (дата обращения: 25.10.2017).

3. Сахно А.В. Образ милиции в российской культуре: конструкция и деконструкция типов восприятия : автореф. дис. ... канд. социол. наук. Ростов н/Д., 2005. 26 с.

4. Полиция: доверие и оценки.

5. Горожанин А.В. Исследование роли и места полиции в механизме обеспечения существования российской государственности // Вопросы экономики и права. 2012. № 3. С. 12-17.

6. Савченко И.А. Рефрорма МВД: взгляд изнутри // Мониторинг общественного мнения: экономические и социальные перемены. 2011. № 2 (102). С. 38-46.

7. Черников В. История создания закона «О полиции» и обзор вносимых изменений [Электронный ресурс] // Профеессионал. Популярно-правовой альманах МВД РФ. URL: http://www.ormvd.ru/pubs/102/the-history-of-the-law-on-policeand-review-the-changes/ (дата обращения: 25.10.2017).

8. Полиция: доверие и оценки.

9. Там же. 


\section{References:}

Chernikov, V 2017, 'Story behind the Law on Police and review of the changes introduced', Professional. Populyarnopravovoy al'manakh MVD RF, viewed 25 October 2017, <http://www.ormvd.ru/pubs/102/the-history-of-the-law-on-police-and-review-the-changes/>, (in Russian).

Gorozhanin, AV 2012, 'Investigation of the role and place of police in the mechanism for ensuring the existence of Russian statehood', Voprosy ekonomiki i prava, no. 3, pp. 12-17, (in Russian).

Hinds, L 2009, 'Youth, police legitimacy and informal contact', Journal of Police and Criminal Psychology, vol. 24, no. 1, pp. 10-21. https://doi.org/10.1007/s11896-008-9031-x.

Murphy, K, Hinds, L \& Fleming, J 2008, 'Encouraging public cooperation and support for police', Policing and Society, vol. 18, no. 2, pp. 136-155. https://doi.org/10.1080/10439460802008660.

Sakhno, AV 2005, The image of police in Russian culture: the construction and deconstruction of types of perception, $\mathrm{PhD}$ thesis abstract, Rostov-on-Don, 26 p., (in Russian).

Savchenko, IA 2011, 'Reform of the Ministry of Internal Affairs: an internal perspective', Monitoring obshchestvennogo mneniya: ekonomicheskiye i sotsial'nyye peremeny, no. 2 (102), pp. 38-46, (in Russian).

Zubok, YuA \& Chuprov, VI 2006, 'Legal culture of the youth in the view of transformational strategies', Sotsiologicheskiye issledovaniya, no. 6, pp. 14-17, (in Russian). 